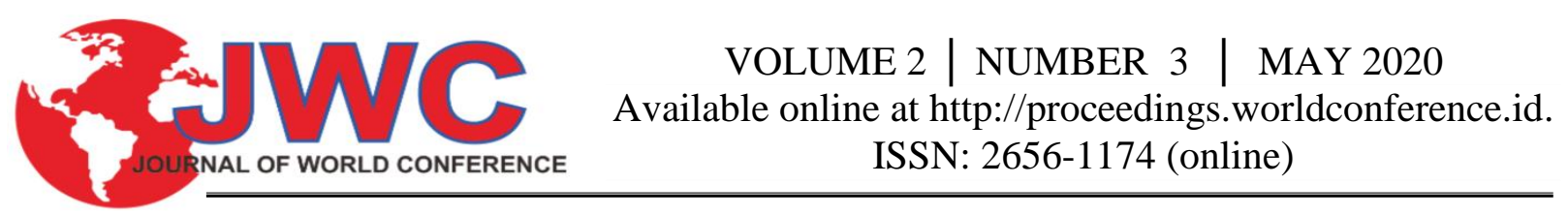

\title{
Juridical Analysis of the Acquittal in a Murder Crime
}

\author{
Chairul Nopriansyah \\ Department of Law, Kader Bangsa University \\ Jl. Ryacudu No.88, SU I, South Sumatera, Palembang, Indonesia \\ nopriansyahchairul628@gmail.com
}

\begin{abstract}
The judge plays an important role in the judiciary because the judge has the authority to examine, hear and decide on a case so that he is obliged to look for values of justice in the application of progressive and responsive laws, so the judge in issuing decisions must pay attention to various considerations. Article 183 of the Criminal Procedure Code contains several elements of judges' considerations when making decisions. In the case of an acquittal, the judge needs carefulness and carefulness to consider so that a matter must be truly convincing. This research is a doctrinal research method that is taking the opinions of experts regarding free decisions and through legal products in the form of legislation and judges' decisions. The conclusion of this paper is First, the basic consideration of the judge in passing a free verdict (vrijspraak) is not fulfilling the minimum limit of evidence by the public prosecutor so that the judge will release the defendant because the evidence that can blame the defendant is insufficient and based on the elaboration of the writer above, the Supreme Court allows legal efforts to overturn an acquittal (vrijspraak) namely an appeal on an acquittal, but not all verdicts requested for appeal are always accepted by the Supreme Court.
\end{abstract}

Keywords:

Acquittal, Consideration of the judge, Vrijspraak.

\section{Introduction}

In principle, the objective of the judge's freedom in hearing and deciding cases is that the court can perform its duties as well as possible so that it can make decisions based on truth, justice and honesty. Therefore, the freedom of judges in deciding cases is a trait of justice. (Sinaga, 2015) A judicial process ends with a final verdict. The Criminal Procedure Code includes 3 (three) possibilities of the judge's conclusion in article 1 point 11 in the form of conviction, free or free from all lawsuits. In the case of an acquittal, the arguments of the public prosecutor and legal advisor both regarding the guilt of the defendant, the conduct of the indictment and with regard to legal evidence, require carefulness and carefulness to consider so that something must be absolutely convincing. If it is not convincing or causes doubt, the judge is obliged to release him, but if the judge erroneously releases the guilty person he will only be faced with juridical accountability for wrongly applying the law. The impulse of an acquittal should be supported by the available evidence. Judge's consideration plays an important role in an acquittal. It is not impossible that a free verdict that has been handed down is not in accordance with applicable legal provisions and ignores the values of justice.

The crime of murder is included in a material criminal act (Materiale delicht), meaning that for the perfection of this criminal act is not enough to do the act, but it is also a condition there is a consequence of the act. Crimes against lives are regulated in Chapter XIX book II of the Criminal Code. The crime of murder is a disturbance to the peace of society and state order. Nowadays a person develops more killing because it is caused by simple things which actually can still be resolved in a family manner so that it can be avoided physical adversity or force Study of the Criminal Code (KUHP) There are several forms or types of criminal acts of murder which are regulated in Article 338 up to Article 350 of the Indonesian Criminal Code. The application of this article has its own limitations, for example, for ordinary killings which are punishable with a maximum sentence of 17 years imprisonment, while premeditated murder is regulated in Article 340 of the Criminal Code which is punishable by life imprisonment or imprisonment for 20 years. We often hear about homicide, the perpetrators of murders are not only done by other people, but can also be carried out by those closest to us who commit the crime of murder, which is part of our family. There are so many cases now that fathers, husbands, uncles, lovers, or even children commit the crime of murder.

One effort to achieve the objectives of the rule of law is to enforce the objectives of criminal procedure law. The purpose of criminal procedure law in the Code of Conduct of Criminal Procedure that we have known is as follows: 


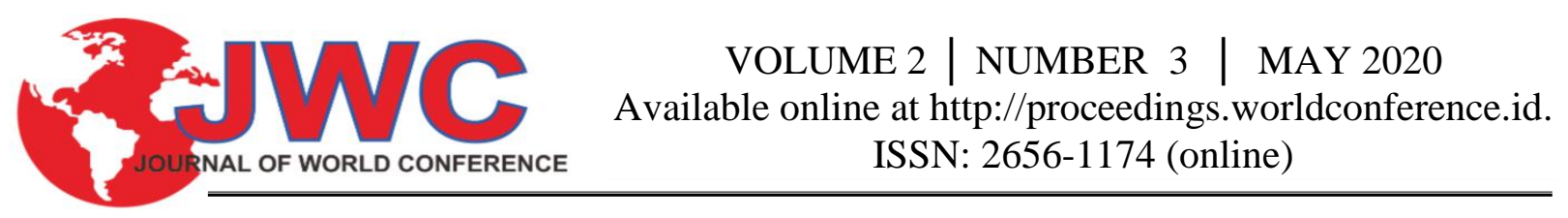

"The purpose of criminal procedure law is to seek and obtain or at least approach material truth is the complete truth of a criminal case by applying the provisions of the criminal procedure law honestly and precisely with the aim of finding out who the perpetrators can be charged with an offense the law and subsequently requests an examination and decision from the court to find out whether it is proven that a criminal offense has been committed and whether the accused person can be blamed. "

The purpose of criminal law seeking truth is only an intermediate goal. The ultimate goal is actually to achieve order, peace, peace, justice and prosperity in society. (Ratama, 2018).

This goal can be achieved through cooperation between law enforcement agencies such as the police, prosecutors, and courts. The unsatisfactory situation of law enforcement in our country is ironically hampered by law enforcers who should set an example to the public in obeying the law and enforcing the law in a pure and consistent manner. (Dewantara, 2014) The court plays a role in the process for justice so that the court must be free and can provide the court without being influenced by any party and in any form. The judge plays an important role in the court because the judge has the authority to examine, hear and decide on a case. In Article 24 paragraph (1) of the 1945 Amendment requires that judicial authority be free to uphold law and justice. Limitation of judges' freedom as a value in their professional obligations is not free as freely as possible but is limited by rules and norms. (Sinaga, 2015) In fact the limitation is not solely determined by law but the freedom of judges is also limited by the values of justice from the bottom of his heart, so that judges in judging and deciding a criminal case must certainly be free from intervention and pressure, coercion, persuasion from anyone. In principle, the objective of the judge's freedom in hearing and deciding cases is that the court can perform its duties as well as possible so that it can make decisions based on truth, justice and honesty. Therefore, the freedom of judges in deciding cases is a trait of justice. A judicial process ends with a final verdict. The Criminal Procedure Code includes 3 (three) possibilities of the judge's conclusion in article 1 point 11 in the form of conviction, free or free from all lawsuits.

In the case of an acquittal, the arguments of the public prosecutor and legal advisor both regarding the guilt of the defendant, the conduct of the indictment and with regard to legal evidence, require carefulness and carefulness to consider so that something must be absolutely convincing. The evidence is intended to prove something, it is important to realize that the evidence presented must foster confidence and can strengthen the position of the judge. If it is not convincing or causes doubt, the judge is obliged to release him, (Marpaung, 2016) but if the judge erroneously releases the guilty person he will only be faced with juridical accountability for wrongly applying the law. (Damoko Yuti Witanto dan Arya Putra Negara Kutawaringin, 2015).

Judges are always faced with two difficult choices between justice and legal certainty but in decisions they must contain and integrate the two. This is in accordance with the function of judges who are not merely mouthpieces of the law, but judges are obliged to look for values of justice in the application of progressive and responsive laws, so judges in passing decisions consider various considerations. The impulse of an acquittal should be supported by the available evidence. Judge's consideration plays an important role in an acquittal. It is not impossible that a free verdict that has been handed down is not in accordance with applicable legal provisions and ignores the values of justice. Based on the description that has been stated above, the researcher in this case is interested in reviewing and examining the problem in writing research with the title "Juridical Analysis of Free Decisions (vrijspraak) in Criminal Acts of Murder". Based on the background, the problems to be examined are:

0 . What is the basis for the judge's judgment in issuing an acquittal (vrijspraak) in a crime of murder?

1. What legal remedies can be taken to overturn a verdict (vrijspraak)?

\section{Literature Review}

Criminal liability is something that is criminally responsible for someone who commits a criminal act or a criminal offense. (Hasbullah, 2018). The theory used in criminal liability is the theory or teaching of error, the basis for criminal prosecution and criminal liability for acts against the law is the element of error from the perpetrator. Without the element of error in an act against the law, the act cannot be convicted. There is no criminal principle without error (nulum poena sine culpa). Error in this case is the existence of a criminal offense that commits and cannot and does not commit acts that meet the elements of a criminal offense.

The forms of error in the teaching of criminal law are as follows:

1. Deliberation (dolus) The Criminal Code does not provide a definition of intent. The definition of intentionality according to Satochid is carrying out an act that is driven by a desire to act or act that is against the law.

2. Negligence (culpa) In addition to the mental attitude which is intentional there is also a mental attitude in the form of negligence. Like intent, the Criminal Code does not provide a definition of the meaning of negligence. So it can be said that negligence arises because a person is alpha, reckless, careless, careless or suspicious. 


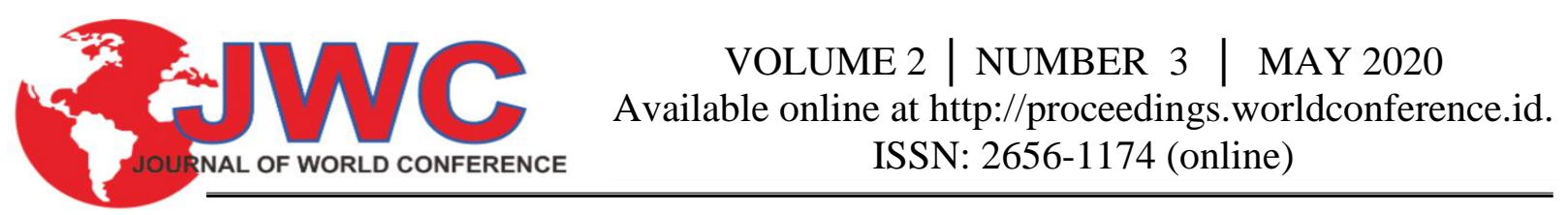

1. Whose elements

The panel of judges concluded that the defendant was the legal subject in this case. Because the defendant is a legal subject in this case, this unity element has been fulfilled.

2. Elements of Participation

The judge considered this element first with the premise that the element was the most essential element and became the substantive / core element of the action as well as the core of the article formulation which was charged by the public prosecutor with the defendant in the alternative indictment. The panel of judges is of the opinion that this element in this article cannot be proven by the public prosecutor, in relation to the facts in the trial there is no correspondence between the description of the prosecutor's indictment with the testimony of the witnesses at the trial, there are not enough 2 (two) pieces of evidence as required by law invite to prove the defendant guilty.

Considerations of judges in the first alternative indictment Article 338 of the Criminal Code:

1. Elements of each person in the trial the defendant is able to answer questions, healthy spiritually and physically so that the defendant is not found on the grounds of things that negate the criminal. From these considerations according to the panel of judges every element of everyone has been fulfilled and proven.

2. The deliberate element of the Panel of Judges considers that the witnesses presented by the public prosecutor in this trial did not see and were suspicious of the defendant committing the act and from the statements of the witnesses when connected with other evidence. The judges also did not get a clue so that the element was not proven according to law.

In the acquittal (vrijspraak) which the author has inventoried, the panel of judges has considered the evidence contained in Article 184 paragraph (1) of the Criminal Procedure Code, the following considerations:

1. Judge's consideration regarding the evidence of witness testimony.

The panel of judges considered witness statements which explained that none of the witnesses saw the defendant in the incident and was suspicious of the defendant committing the act. The judge considered all witness statements, even though all were denied by the defendant, the judge did not forget to consider the suitability of the witness. (Sulistiani, 2015)

2. Judge's consideration regarding the evidence of the letter.

Letter evidence that became the judge's consideration in the three decisions was evidence of the Minutes of Examination (BAP) at the investigation level. In addition to the consideration of letter evidence in the form of BAP, in all three decisions the panel of judges also considered visum et repertum made by experts namely doctors. (Barama, 2016) Visum et repertum can answer at least two questions in a crime, including:

$1 . \quad$ Is there really a result for the victim?

2. What is it caused by so that that effect arises? While regarding who the perpetrators who have caused the effects cannot be answered by autopsy report results or the results of the post mortem revision because they can answer that is the witness's testimony or instructions.

\subsection{Legal Efforts That Can Be Done To Cancel The Free Decision (Vrijspraak)}

The prohibition of cassation against a free verdict (vrijspraak) is, of course, seen as too idealistic and not in accordance with the situation and conditions of the Indonesian people. In short, the Supreme Court does not produce jurisprudence that is contrary to the law, the Supreme Court actually straightens the application of the law carried out by the court so that the application of the law is truly in accordance with the meaning and meaning contained therein, therefore for the sake of law, truth and justice, The Supreme Court justifies filing an appeal against the acquittal. (Husin, 2012).

In addition to the Supreme Court's ruling, a free verdict can be appealed with the Constitutional Court's ruling no. 114 / PUU-X / 2012 dated 28 March 2013 which states the phrase "except for an acquittal" in Article 244 of Law No. 8 of 1981 is contrary to the constitution and does not have binding legal force, the Supreme Court has the authority to examine the appeal application for a free award to allow an appeal for a free decision (vrijspraak). (Dwi Marieta Darmastuti dan Lita Arofu Nurhidayah, 2015)

Based on the author's explanation above, the Supreme Court allows the appeal of a free decision (vrijspraak) but not all of the free decisions requested for cassation are always accepted by the Supreme Court. The Supreme Court considers the cassation of a verdict of pure or impure nature.

Reason for Cassation on Free Verdict (Vrijspraak) The public prosecutor should make an appeal memory in accordance with Article 235 paragraph (1) of the Criminal Procedure Code as has been described by the author, but the public prosecutor should be able to prove and describe the cassation memory carefully, clearly and completely that the free verdict requested is requested. The appeal is a decision containing an impure exemption that is a release based on an error in the application of the law, for example, a release based on a misinterpretation of a term 


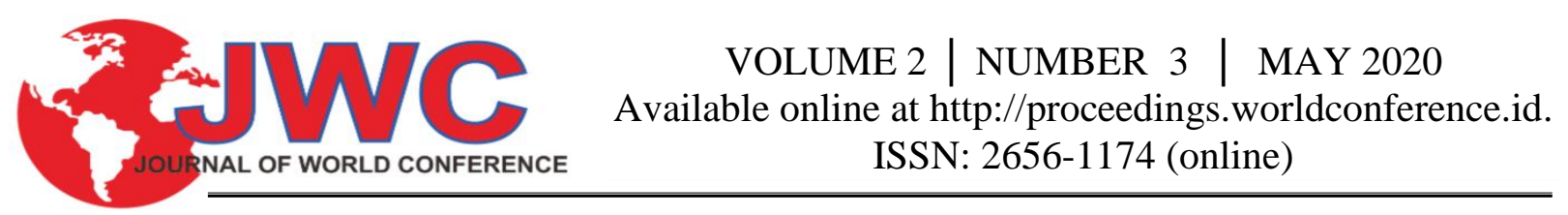

contained in the indictment or the exemption is actually a release from all legal claims, but because the mistake of applying the ruling reads release.

\section{Conclussion}

1. The basis for the judge's judgment in issuing an acquittal (vrijspraak) is that the public prosecutor has not fulfilled the minimum threshold of proof so that the judge will acquit the defendant because the evidence which can blame the accused is insufficient. The suitability of the free decision (vrijspraak) is related to the applicable law, according to the author the decision handed down is appropriate because after going through the trial process and based on consideration of the available evidence and the judge's conviction that the defendant is innocent. The panel of judges also considers the evidences listed in Article 184 paragraph (1), then the writer specifies the judges' considerations so that it can be seen that the judge really considers the evidence.

2. Based on the elaboration of the writer above, the Supreme Court allows legal efforts to overturn the verdict (vrijspraak), namely the appeal of the acquittal, but not all the verdicts requested for appeal are always accepted by the Supreme Court. If the acquittal requested for appeal contains a genuine release, the Supreme Court will declare that the appeal is unacceptable.

\section{Suggestion}

First, judges in deciding a case must always adhere to the applicable laws that have been determined and the rules of the Law and are supported by their beliefs because the verdict handed down by the judge is the responsibility of the judge towards Allah, the nation and state, the law, and the community. Second, the Judge should consider appropriately in accordance with the facts in the trial and the applicable law in deciding a case so as to cause a sense of justice for all parties and the public.

\section{References}

Barama, M. 2016. Kedudukan Visum Et Repertum dalam Hukum Pembuktian Manado. Jurnal Lex et Societatis.

Damoko Yuti Witanto dan Arya Putra Negara Kutawaringin. 2015. Diskresi Hakim sebuah Instrumen Menegakkan Keadilan Substanstif dalam perkara- Perkara Pidana. Bandung: ALFABETA.

Dewantara, N. A. 2014. Msalah Kebebasan Hakim dalam Menangani Suatu Perkara Tindak Pidana. Jakarta: Aksara Persada Indonesia.

Dwi Marieta Darmastuti dan Lita Arofu Nurhidayah. 2015. Tinjauan Tentang Upaya Hukum Kasasi Penuntut Umum Terhadap Putusan Bebas dalam Perkara Korupsi. Jurnal Verstek, 9.

Hasbullah, F. S. 2018. Teori Pertanggungjawaan Pidana. Jakarta: Prenada Media.

Husin, H. M. 2012. Kasasi sebagai Upaya Hukum. Jakarta: Sinar Grafika.

Junaidi, E. 2018. Rekonstruksi Dasar Pertimbangan Hakim. Jakarta: Prenada Media.

Marpaung, L. 2016. Putusan Bebas Masalah dan Pemecahannya. Jakarta: Sinar Grafika.

Ratama, T. H. 2018. Teori dan Praktik Hukum Acara Pidana Khusus. Jakarta: Pustaka Setia.

Sinaga, D. 2015. Kemandirian dan Kebebasan Hakim Memutus Perkara Pidan dalam Negara Hukum Pancasila. Jakarta: Nusamedia.

Sugiyono. 2012. Metode Penelitian Kuantitatif dan R\&D. Bandung: Alfabeta.

Sulistiani, R. 2015. Tinjauan Tentang Upaya Hukum Kasasi Penuntut Umum Terhadap Putusan Bebas Dalam Perkara Korupsi (Studi Kasus dalam Putusan Mahkamah Agung Nomor 1366K/Pid.Sus/2013). Jurnal Verstek, 9.

\section{Biography}

Chairul Nopriansyah is a graduate student of Master of Law at Kader Bangsa University and also an advocate. He started school in 1992-1998 at Elementary School Number 6 in Baturaja; in1998-2001 at Junior High School Sentosa Bhakti in Baturaja; in 2002-2005 at Senior High School Yayasan Pendidikan Kadar Pembangunan in Baturaja. Then, Nopriansyah continued studying in 2005-2009 at Sjakhyakirti University in Palembang. After that, for quite a long time in 2018, he continued his Masters of Law at Kader Bangsa University in Palembang. 